\title{
Establishment of Antifungal Phyllospheric Bacteria in Potato (Solanum tuberosum L.)
}

\author{
Satish Kumar ${ }^{1}$, Deepika Chaudhary ${ }^{1}$, Rashmi ${ }^{1}$, Raman Jangra ${ }^{1}$, \\ Anju Kumari ${ }^{2}$ and Rakesh Kumar ${ }^{*}$ \\ ${ }^{1}$ Department of Microbiology, CCS Haryana Agriculture University, \\ Hisar-125004, Haryana, India \\ ${ }^{2}$ Centre of Food Science and Technology, CCS Haryana Agriculture University, \\ Hisar-125004, Haryana, India \\ *Corresponding author
}

\section{A B S T R A C T}

The phyllosphere supports a large and complex bacterial community that varies both across plant species and geographical locations. Phyllosphere bacteria can have important

Keywords

Potato, Leaf,

Antifungal,

Bacterial count

Article Info

Accepted:

10 March 2018

Available Online:

10 April 2018 effects on plant health. Many fungal diseases leads to important crop loss and due to limited antifungal availability and effectiveness in agriculture practices, it appears necessary to develop alternative control strategies. A total of 46 bacteria isolates were obtained from phyllosphere of different crops (Wheat, Pearl millet, Cotton, Mungbean and Potato). All the bacterial isolates were characterized for antifungal activity against Aspergillus niger and Rhizoctonia solani. Only Eighteen bacterial isolates showed the growth inhibition of phyto-pathogenic fungi against $A$. niger. and $R$. solani. On the basis of plant growth promotion traits, a total of seven isolates (POK-3, WHN-2, WHN-1, PMK-3, WHK-2, COJ-4, and MUK-1) were applied as foliar spray. The plants inoculated with the phyllospheric bacterial isolates recorded as biocontrol against phyto pathogenic fungi $A$. niger and $R$. solani. Therefore, it can be concluded that application of PGPB has immense potential to be used as biocontrol as they promote plant growth as well as improve the health and yield of the plants.

\section{Introduction}

Potato (Solanum tuberosum L.) is a member of solanaceae family and considered as one of the most valuable and widely distributed crops that is used for human food in most part of the world. It yields exceptionally high, produces more energy that is edible and protein per unit area and time than many crops. This also fits well in multiple cropping systems prevalent under tropical and subtropical agro-climatic conditions. Bacterial-host interaction can be harmful for the host (pathogenic interaction) or useful (symbiotic interaction). To have an optimal interaction, bacteria have to fine-tune itself with the biotic and abiotic environmental conditions of the host plant. This can be achieved via expression or repression of essential traits, such as host detection, motility towards the host, colonization and resistance 
to host defences, growth and reproduction. The ability to quickly adapt to host environments is therefore critical for bacteria to have successful association with host. The phyllosphere refers to leaf surfaces, or total above ground surfaces, of plants as a habitat for microorganisms. Phyllosphere term was given by Ruinen (1961). Phyllosphere is the leaf surfaces or total above-ground surfaces of a plant as a habitat for microorganisms. All plants are host to a numerous and diverse community of microorganisms including bacteria, fungi and yeasts. The study of the characteristics of microbial life in the phyllosphere is of great commercial importance to the agricultural industry because of two reasons. One is to understand the survival of plant disease-causing bacteria and fungi while other is to develop new ways to control their spread (Lindow and Brandl, 2003; Leveau, 2006). Phyllosphere bacteria can promote plant growth and both suppress or stimulate the colonization and infection of tissues by plant pathogens (Lindow and Brandl, 2003). Phyllosphere microbiology has much to offer to the field of microbial ecology and promises to contribute the more effective and less environmentally damaging means of plant protection. Indole acetic acid (IAA) is one of the most physiologically active auxins. IAA is a common product of L-tryptophan metabolism by several microorganisms. Also, indole-3-acetic acid (IAA), the major naturally occurring auxin, is a signalling molecule in microorganisms because IAA affects gene expression in some microorganisms (Spaepen and Vanderleyden, 2016). They can also be involved in plant protection, which is due to direct interactions of microorganisms through the production of antibiotic compounds and competition for resources (Berg, 2009). Additionally, microorganisms may protect plants against the pathogens by inducing systemic resistance (Conrath et al., 2006; Pieterse et al., 2012). PGPB can act as biocontrol agents by the formation of secondary metabolites like siderophore, HCN and by certain enzyme activity like chitinase, cellulase, protease and peroxidase etc. that showed toxic effect against plant pathogens (antifungal activity) (Labuschagne et al., 2010; Nabti et al., 2014). So, the internal and external foliar microbiota and their likely key roles in plant performance, growth and health, currant studies to understand better plant functioning and its responses and effects in a changing world, the importance and role of bacteria in phyllosphere make it available to the plants.

\section{Materials and Methods}

\section{Isolation of bacteria from the phyllosphere} of different crops

Bacteria were isolated from the phyllosphere of different crops (Wheat, Potato, Cotton, Mung bean and Pearl millet) grown at CCS HAU research farm. For isolation, $10 \mathrm{~g}$ of fresh leaves were added into $90 \mathrm{ml}$ sterilized distilled water and placed on rotary shaker for half an hour. Serial dilutions (up to $10^{-5}$ ) of samples were made in $9.0 \mathrm{ml}$ sterilized water blanks and $0.1 \mathrm{ml}$ of appropriate dilution was spread on different (Nutrient agar, King's B medium and Jensen's $\mathrm{N}_{2}$ free medium) media plates. The plates were incubated at $28 \pm 2^{\circ} \mathrm{C}$ in a BOD incubator for 2-3 days. Based on the morphotypes, different bacterial colonies were selected, maintained and purified on respective media slants.

\section{Determination of antifungal activity}

The antagonistic interaction of bacterial isolates with Rhizoctonia solani and Aspergillus niger was studied by the spot test method on potato dextrose agar (PDA) medium plates (Sindhu et al., 1999). Fungi were grown on PDA slants for 4 days and spore suspension was harvested in $2 \mathrm{ml}$ sterilized water. About $0.1 \mathrm{ml}$ of fungal spore 
suspension was spread over fresh PDA medium plates. Loopful growth of 48-hours old cultures of different bacterial isolates was spotted on each plate. The growth inhibition of phyto pathogenic fungi around the spotted bacterial growth was recorded after 4 days old incubation at $28 \pm 2^{0} \mathrm{C}$.

Establishment of antifungal bacterial isolates vis-à-vis PGPB in phyllosphere of potato

A pot house experiment was conducted to test the survival and growth of antifungal bacterial isolates in the phyllopshere of potato. Total viable count in different treatments reflects the establishment of particular isolates in phyllopshere of potato under screen house.

\section{Total bacterial population in phyllosphere}

Total viable counts in phyllosphere of potato plant were taken at an interval of 30, 60 and 90 days. $10 \mathrm{~g}$ of fresh leaves were added into $90 \mathrm{ml}$ sterilized distilled water and further serially diluted and hundred $\mu \mathrm{l}$ of each sample from various dilutions $\left(10^{-3}, 10^{-4}\right.$ and $\left.10^{-5}\right)$ were spread over nutrient agar plates. The plates were incubated for $3-5$ days at $28 \pm 2^{\circ} \mathrm{C}$ and colonies appeared were counted. The counts were calculated on per g leaf basis using formula:

No. of cfu (colony forming units) $\mathrm{x}$ dilution factor/ volume taken (ml)

\section{Results and Discussion}

\section{Isolation of bacteria from the phyllosphere of different crops}

A total of forty six bacterial isolates were retrieved from five phyllospheric leaf samples (wheat, potato, cotton, pearl millet and mung bean) using dilution plating on Nutrient agar media, King's B media and Jensen's $\mathrm{N}_{2}$ free media (Table 1). Microorganisms in the phyllosphere can promote plant growth by different mechanisms, e.g. through production of hormones. They can also be involved in plant protection, which is due to direct interactions of microorganisms through the production of antibiotic compounds and competition for resources (Wu et al., 2009). Additionally, microorganisms may protect plants against the pathogens by inducing systemic resistance (Pieterse et al., 2012). Internal and external foliar micro biota have many other functions, including indirect protection against pathogens, through the interaction of commensal bacteria with the foliar plant pathogen (Arnold et al., 2003) or communication through their contribution to different types and quantities of emissions of volatile organic compounds (Bulgerelli et al., 2013).

\section{Screening of different isolates for plant growth promoting traits}

All the bacterial isolates were screened for antifungal activity. Figure 1 (a) and 1 (b) shows the growth inhibition of phyto pathogenic fungi around the spotted bacterial growth on PDA medium plates. Eighteen bacterial isolates showed the growth inhibition of phyto pathogenic fungi against A. niger. \& $R$. solani. Maximum antifungal activity was observed in isolate PMK3 followed by COJ4 and WHN1.

Phyllosphere bacteria can affect plant growth indirectly by protecting plants against pathogens. These microbial communities may be involved in plant protection, due to direct interactions of resident microorganisms those produce antibiotic compounds and showed competition for resources. Phyllosphere bacteria can affect plant growth indirectly by protecting plants against pathogens. These microbial communities may be involved in plant protection, due to direct interactions of 
resident microorganisms those produce antibiotic compounds and showed competition for resources (Berg, 2009). Such antagonistic effects have been demonstrated for several leaf-colonizing bacterial isolates. Large epiphytic strain collections were screened for inhibitory effects in vitro, e.g. by agardiffusion assays or streak tests with laboratory cultures (May et al., 1997; Adhikari et al., 2001). Braun et al., (2010) showed that the toxin-producing isolate $P$. syringae pv. syringae $22 \mathrm{~d}$ inhibited growth of the nearisogenic foliar pathogen $P$. syringae pv. glycinea in vitro, but was not responsible for the antagonistic effects observed in planta. Abundant non-pathogenic soil microbes rapidly colonize plant surfaces and use most of the available nutrients, making it difficult for pathogens to grow. For example, in one series of experiments, researchers demonstrated that treatment of plants with the leaf bacterium Sphingomonas spp. prevented the bacterial pathogen Pseudomonas syringae pv. tomato from causing pathogenic symptoms (Innerebner et al., 2011). However, for other strains it was shown that antibiosis is involved in plant protection. For instance, a Tn5 mutant of Pantoea agglomerans Eh 252 deficient in antibiotic production was not as effective as the wild type strain to control fire blight in the field (Stockwell and Peterson, 2002). Antimicrobial compounds are produced by microorganisms to remain competitive in their environment by diminishing growth of other bacteria.

Establishment of antifungal bacterial isolates vis-à-vis PGPB in phyllosphere of potato

A pot house experiment was conducted to test the survival and growth of antifungal bacterial isolates in the phyllopshere of potato. After 20 days of sowing, selected bacterial isolates were sprayed on phyllosphere according to the treatments (Table 2).

Table.1 List of bacteria isolated from phyllosphere of different crops

\section{Site of collection of leaf samples}

Wheat phyllosphere HAU research farm, Hisar

Potato phyllosphere HAU research farm, Hisar

Cotton phyllosphere HAU research farm, Hisar

Pearl millet phyllosphere HAU research farm, Hisar

Mung bean phyllosphere HAU research farm, Hisar Total no. of isolates
Medium used for isolation

Nutrient agar

WHN1,WHN2, WHN3, WHN4, WHN5, WHN6 PON1

CON1

PMN1

MUN1, MUN2, MUN3, MUN4

MUK1, MUK2, MUK3, MUK4

WHK5, WHK6

POK1, POK3, POK4, POK5

PMK1, PMK2, PMK3,

PMK4, PMK5, PMK6
No. of isolates medium

WHJ1, WHJ2, WHJ3

POJ1, POJ2
COK2, COK3, COK4, COK5
COJ1, COJ4

PMJ1

MUJ1

9 
Table.2 Total viable count (bacteria) in the phyllosphere of potato crop under pot-house condition (log cfu/g leaves)

\begin{tabular}{|c|l|c|c|c|}
\hline Treatment & DETAILS & 30 DAS & 60 DAS & 90 DAS \\
\hline T1 & CONTROL & 6.3 & 6.3 & 6.0 \\
\hline T2 & 75\%RDF (Recommended dose of fertilizer) & 6.6 & 6.5 & 6.6 \\
\hline T3 & RDF (Recommended dose of fertilizer) & 6.6 & 6.6 & 6.7 \\
\hline T4 & 75\% RDF + Mac27 (Tuber treatment) & 6.8 & 6.6 & 7.4 \\
\hline T5 & RDF + Mac27 (Tuber treatment) & 6.8 & 6.8 & 7.4 \\
\hline T6 & 75\% RDF + Mac27 (Foliar treatment) & 6.9 & 7.0 & 7.3 \\
\hline T7 & RDF + Mac27 (Foliar treatment) & 6.9 & 7.3 & 7.4 \\
\hline T8 & 75\% RDF + Bacterial isolate POK-3 spray & 7.8 & 7.5 & 7.5 \\
\hline T9 & RDF + Bacterial isolate POK-3 spray & 7.6 & 7.5 & 7.5 \\
\hline T10 & 75\% RDF + Bacterial isolate WHN-2 spray & 7.6 & 7.7 & 7.5 \\
\hline T11 & RDF + Bacterial isolate WHN-2 spray & 7.3 & 7.8 & 7.5 \\
\hline T12 & 75\% RDF + Bacterial isolate WHN-1 spray & 7.7 & 7.6 & 7.5 \\
\hline T13 & RDF + Bacterial isolate WHN-1 spray & 7.7 & 7.7 & 7.6 \\
\hline T14 & 75\% RDF + Bacterial isolate PMK-3 spray & 8.0 & 7.7 & 7.8 \\
\hline T15 & RDF + Bacterial isolate PMK-3 spray & 7.6 & 7.8 & 7.8 \\
\hline T16 & 75\% RDF + Bacterial isolate WHK-2 spray & 7.9 & 7.7 & 7.7 \\
\hline T17 & RDF + Bacterial isolate WHK-2 spray & 7.4 & 7.8 & 7.7 \\
\hline T18 & 75\% RDF + Bacterial isolate COJ-4 spray & 7.5 & 7.8 & 7.5 \\
\hline T19 & RDF + Bacterial isolate COJ-4 spray & 7.8 & 7.6 & 7.7 \\
\hline T20 & 75\% RDF + Bacterial isolate MUK-1 spray & 6.9 & 7.5 & 7.4 \\
\hline T21 & RDF + Bacterial isolate MUK-1 spray & 7.4 & 7.5 & 7.4 \\
\hline C.D. at 5\% & & 0.28 & 0.26 & 0.30 \\
\hline
\end{tabular}

Fig.1 (a) Antifungal activity exhibited by bacterial isolates against Aspergillus niger
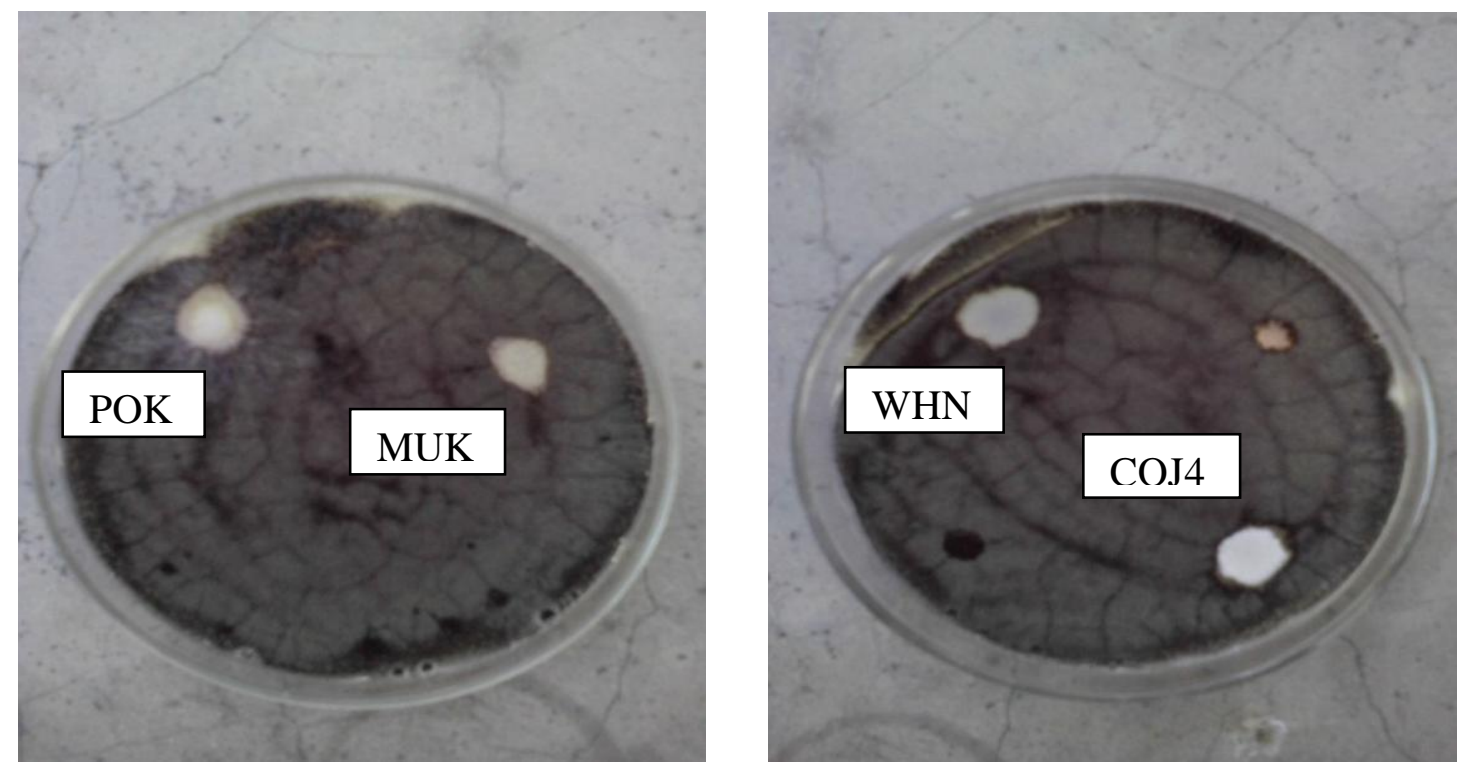
Fig.1 (b) Antifungal activity exhibited by bacterial isolates against $R$. solani
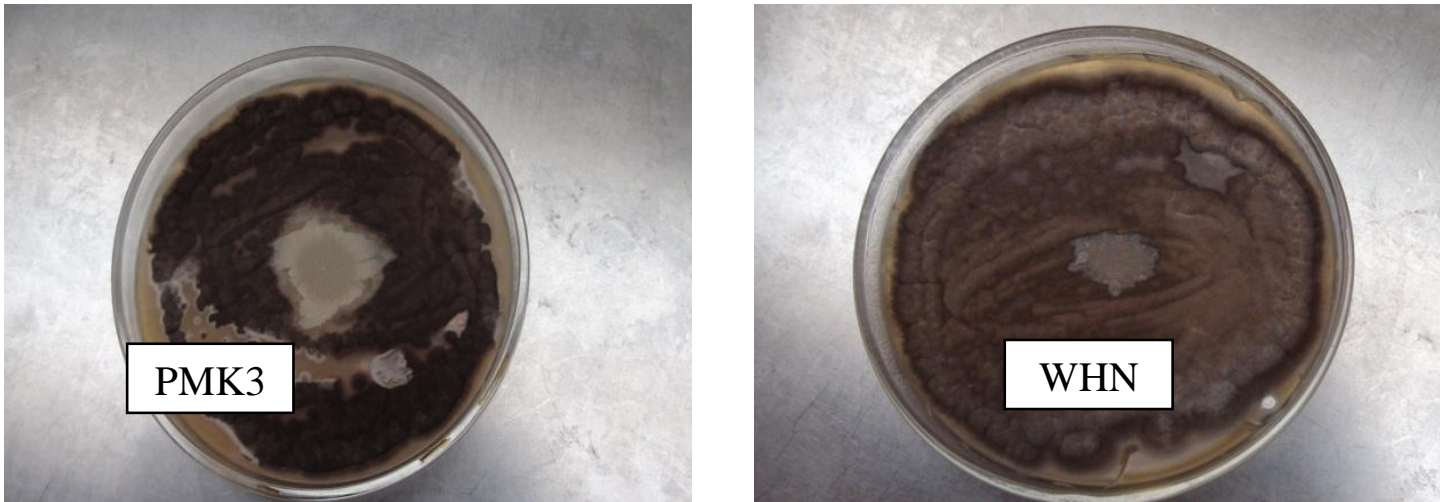

Fig.2 Comparative plant growth of potato crop in different treatments (Before and after blight attack)

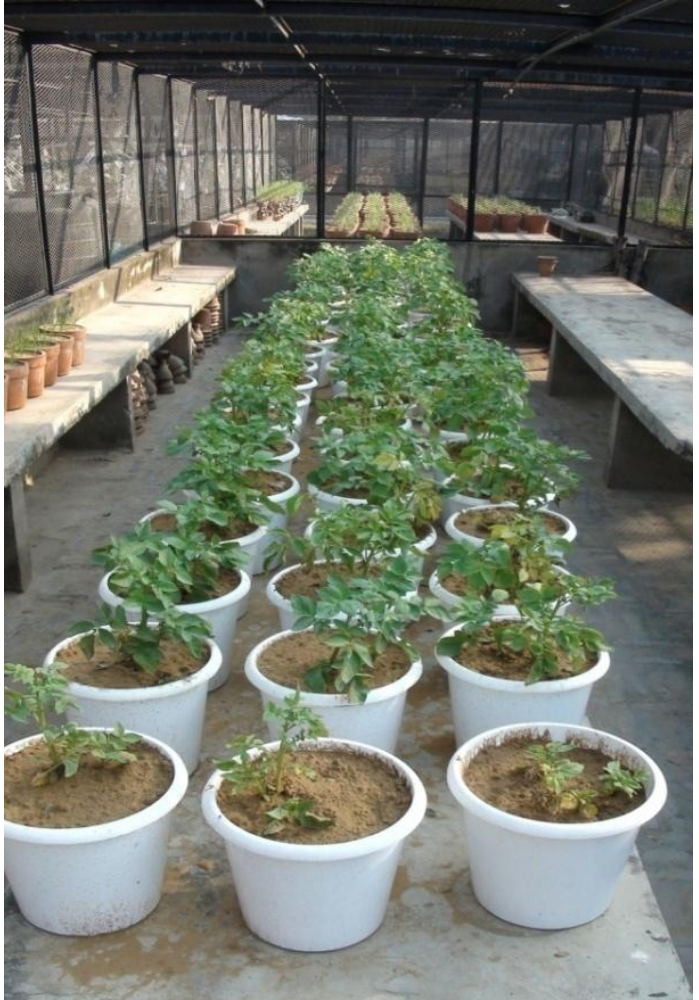

Bacterial count in phyllosphere of potato plant

The microbial communities of leaves are diverse and include many different genera of bacteria, filamentous fungi, yeasts and algae which are important for plant health and growth (Whipps et al., 2008; Vorholt, 2012).

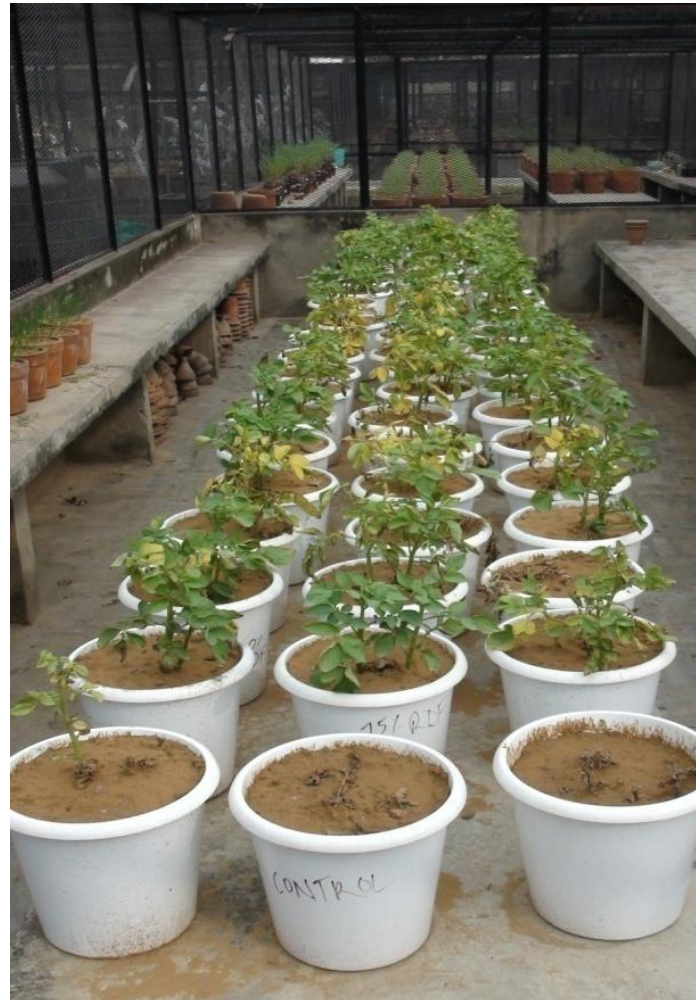

The epiphyte population is dominated by bacteria which can be found in numbers ranging from $10^{5}$ to $10^{7}$ cells/g of plant material (Yadav et al., 2005). Artur et al., (2015) reported that a bacterial isolate called $49 \mathrm{M}$, showing protective activity against fire blight caused by the bacterium Erwinia amylovora, was selected from a large 
collection of isolates obtained from the apple phyllosphere and was identified as Pseudomonas graminis, based on its phenotype and sequence analysis of the $16 \mathrm{~S}$ rRNA and rpoD genes.

Total viable count (phyllosphere) was determined in all the treatments at 30,60 and 90 DAS. Total phyllospheric viable count was observed maximum in foliar application of isolate PMK3 along with RDF i.e. treatment T15 (7.8 log cfu/g leaves) followed by foliar application of isolate WHK2 and COJ4 along with RDF i.e. treatment T17 \& T19 (7.7 log cfu/g leaves) at 90 DAS. The viable count in all the treatments increased till 90 DAS (Table 2). Total viable count ranged from 6.3$8.0 \log$ no. cfu/leaves at 30 DAS, from $6.3-$ $7.8 \mathrm{log}$ no. cfu/leaves at $60 \mathrm{DAS}$ and from 6.00 - $7.8 \log$ no. cfu/leaves at 90 DAS which were non- significantly differed from one another.

The increased in phyllosphere viable count in treatment T15 indicates the establishment of isolate PMK3 in the phyllosphere of potato. The establishment of isolate PMK3 in potato phyllosphere results into better growth and yield attributing traits over the other treatments (Fig. 2).

Akter et al., (2015) studied three bacterial isolates namely UMB20, KMB25 and BMB42 obtained from rice plants which showed the ability of biocontrol and plant growth promotion. Fungal growth inhibition by the isolates ranged from 86.85 to $93.15 \%$ in volatile and $100 \%$ in diffusible metabolites test. Among the isolates, BMB42 showed fungal growth inhibition significantly in the volatile metabolite test. Among the three isolates, KMB25 showed protease production and all of them were negative to pectinase and lipase and positive to the production of siderophore, and $\mathrm{HCN}$, and were able to solubilize tricalcium phosphate.
Annalisa et al., (2016) reported that sixty out of 162 bean rhizobacteria inhibited the growth in vitro of selected virulent strains of both varieties of Xanthomonas axonopodis pv. phaseoli and, when applied to seeds before sowing, six of them showed reduced disease symptoms on bean in in vitro and greenhouse pathogenicity assays. In order to deepen bacteria characterization, the six rhizobacteria were evaluated for lytic enzymes, hydrogen cyanide, ammonia, siderophores, indoles production, inorganic phosphates solubilisation and environmental adaptability in terms of salinity, $\mathrm{pH}$ and temperature gradients variation. Altogether the findings of this study indicate the above six rhizobacteria as potential biocontrol candidate.

\section{References}

Adhikari, T.B., Joseph, C.M., Yang, G.P., Phillips, D.A. and Nelson, L.M. 2001. Evaluation of bacteria isolated from rice for plant growth promotion and biological control of seedling disease of rice. Can. J. Microbiol., 47: 916-924.

Akter, S., Kadir, J., Juraimi, A. S. and Saud, H. M. 2016. In vitro evaluation of Pseudomonas bacterial isolates from rice phyloplane for biocontrol of Rhizoctonia solani and plant growth promoting traits. J. Environ. Biol., 37: 597-602.

Annalisa, G., Cantore, P. L., Shanmugaiah, V., Lamorte, D. and Iacobellis, N. S. 2016. Rhizobacterial isolated from common bean in southern Italy as potential biocontrol agent against common bacterial blight. Eur. J. Plant Pathol., 144: 297-309.

Arnold, A.E., Mejia, L.C., Kyllo, D., Rojas, E.I., Maynard, Z., Robbins, N. and Herre, E.A. 2003. Fungal endophytes limit pathogen damage in a tropical tree. Proc. Nati. Acad. Sci. U.S.A., 100: 15649-15654. 
Artur, M., Sobiczewski, P., Pulawska, J. and Maciorowski, R. 2016. Control of fire blight (Erwinia amylovora) by a novel strain 49M of Pseudomonas graminis from the phyllosphere of apple (Malus spp.). European Journal of Plant Pathology, 145: 265-276.

Artur, M., Sobiczewski, P., Pulawska, J. and Maciorowski, R. 2016. Control of fire blight (Erwinia amylovora) by a novel strain 49M of Pseudomonas graminis from the phyllosphere of apple (Malus spp.). Eur. J. Plant Pathol., 145: 265276.

Berg, G. 2009. Plant-microbe interactions promoting plant growth and health: perspectives for controlled use of microorganisms in agriculture. Appl. Microbiol. Biotechnol., 84: 11-18.

Braun, S.D., Hofmann, J., Wensing, A., Weingart, H., Ullrich, M.S. and Spiteller, D. 2010. In vitro antibiosis by Pseudomonas syringae Pss22d, acting against the bacterial blight pathogen of soybean plants, does not influence in planta biocontrol. J. Phytopathol., 158: 288-295.

Bulgarelli, D., Schlaeppi, K., Spaepen, S., Themaat, E and Lefert, P. 2013. Structure and functions of the bacterial microbiota of plants. Annu. Rev. Plant Biol., 64: 807-838.

Conrath, U., Beckers, G.J., Flors, V., GarciaAgustin, P. and Jakab, G. 2006. Priming: getting ready for battle. Mol. Plant Microbe Interact., 19: 10621071.

Innerebner, G., Knief, C. and Vorholt, J.A. 2011. Protection of Arabidopsis thaliana against leaf-pathogenic Pseudomonas syringae by Sphingomonas strains in a controlled model system. Appl. Environ. Microbiol., 77, 3202-3210.

Labuschagne, N., Pretorius, T. and Idris, A. H. 2010. Plant growth promoting rhizobacteria as biocontrol agents against soil-borne plant diseases. Microbiology Monographs., 18: 211230.

Leveau, J. H. J. 2006. Microbial communities in the phyllosphere. Biol Plant Cuti., (Riederer $\mathrm{M}$ and Muller $\mathrm{C}$, eds), pp. 334-367. Blackwell, Oxford.

Lindow, S.E. and Brandl, M.T. 2003. Microbiology of phyllosphere. Appl. Environ. Biol., 69: 1875-1883.

May, R., Volksch, B. and Kampmann, G. 1997. Antagonistic activities of epiphytic bacteria from soybean leaves against Pseudomonas syringae pv. glycinea in vitro and in planta. Microb. Ecol., 34: 118-124.

Nabti, A. E., Bensidhoum, L., Tabli, N., Dahel, D., Weiss, A., Rothballer, M., Schmid, M. and Hartmann, A. 2014. Growth stimulation of barley and biocontrol effect on plant pathogenic fungi by a Cellulosimicrobium sp. strain isolated from salt-affected rhizosphere soil in northwestern Algeria. E. J. Soil Biol., 61: 20-26.

Pieterse, C.M., Van der Does, D., Zamioudis, C., Leon-Reyes, A. and Van Wees, S.C. 2012. Hormonal modulation of plant immunity. Annu. Rev. Cell Dev. Biol., 28: 489-521.

Sindhu, S. S., Gupta, S. K. and Dadarwal, K. R. 1999. Antagonistic effect of Pseudomonas spp. on pathogenic fungi and enhancement of growth of green gram (Vigna radiata). Biol. Fert. Soils., 29: 62-68.

Spaepen, S. and Vanderleyden, J. 2016. Auxin and Plant-Microbe Interactions. Cold Spring Harb.Persp. Biol., doi: 10.1101/cshperspect.a001438.

Stockwell, D.R.B. and Peterson, A.T. 2002. Controlling bias in biodiversity data. (eds J.M. Scott, P.J. Heglund, M. Morrison, J.B. Haufler, M.G. Raphael, W.A. Wall \& F.B. Samson), Predicting 
Species Occurrences: Issues of Scale and Accuracy. Washington, DC: Island Press; 537-546.

Vorholt, J.A. 2012. Microbial life in the phyllosphere. Nature Rev. Microbiol., 10: $828-840$.

Whipps, J.M., Hand, P., Pink, D. and Bending, G.D. 2008. Phyllosphere microbiology with special reference to diversity and plant genotype. J, Appl. Microbiol., 105: 1744-1755.

$\mathrm{Wu}$, C.H., Bernard, S., Andersen, $\mathrm{G}$ and Chen, W. 2009. Developing microbe- plant interactions for applications in plant-growth promotion and disease control, production of useful compounds, remediation and carbon sequestration. Microb. Biotechnol., 2: $428-440$.

Yadav, R.K.P., Karamanoli, K. and Vokou, D. 2005. Bacterial colonization of the phyllosphere of mediterranean perennial species as influenced by leaf structural and chemical features. Microb. Ecol., 50: $185-196$.

\section{How to cite this article:}

Satish Kumar, Deepika Chaudhary, Rashmi, Raman Jangra, Anju Kumari and Rakesh Kumar. 2018. Establishment of Antifungal Phyllospheric Bacteria in Potato (Solanum tuberosum L.). Int.J.Curr.Microbiol.App.Sci. 7(04): 1048-1056. doi: https://doi.org/10.20546/ijcmas.2018.704.115 